International Journal of Instruction e-ISSN: 1308-1470 • www.e-iji.net
July $2021 \bullet$ Vol.14, No.3

p-ISSN: 1694-609X

pp. $i-i v$

OnlineFirst: 30/04/2021

\title{
Democracy Education in Switzerland, Known for its Strong Democracy ${ }^{1}$
}

\author{
Dear Readers,
}

Switzerland is known for its strong democracy that has been exercised continuously for hundreds of years. Thanks to the diversity of its geography, it accommodates different cultures that significantly affect the country's languages and culture. This federal country has three official and a semi-official languages, German, French, Italian and a little Romani are spoken. Having four different official languages and practicing these fourlanguages in all areas of life can be counted as perfect democracy examples.

Democracy education in Switzerland is included in school programs with multilingualism and multiculturalism. Many different workshops and extracurricular activities are offered for students and teachers. The term democracy and democratic behaviors are immersed in almost every textbook (history, society, language lessons).

There are many in-service classes on education for democracy offered to teachers. This is not just about democracy, however democratic terms are generally part of these courses. For example, holding a workshop on designing exercises on children's rights in the classroom is an example for this situation.

Along with the new curriculum "Lehrplan21" (for German speaking cantons), instructions on democracy education from preschool to the end of compulsory education have been included in the program. Thus, teachers are now tasked with officially doing what has been done in many Swiss schools for decades.

In this context, what democratic institutions and processes are, the meaning of the principle of separation of powers, the importance of human rights, civic duties, taking active part in civil society, how to read the media, to be able to critically analyze, to have a more independent perspective on political issues, to work together, to communication skills, analyzing and solving problems, critical analysis, reflecting on a topic, reaching a consensus and defending in a discussion, etc. topics have been included in the program (Swissinfo, 2021).

\footnotetext{
${ }^{1}$ Discussions were held with teachers on democracy education in Switzerland. We sincerely thank these valuable teachers who contributed to the preparation of this article with their information.

Citation: Ari, A. \& Schmitt, N. (2021). Democracy Education in Switzerland, Known for its Strong Democracy: From the Editor. International Journal of Instruction, 14(3), i-iv. https://doi.org/10.29333/iji.2021.1430a
} 
In the Swiss education system, raising the awareness of students about democracy, democratic participation and personal rights is a normal in-class activity. The weekly "Klassenstunde (classroom lecture)" or "Klassenrat (class council)" is very common, where students are invited to participate in the organization and decision-making processes. In primary schools, there is one hour a week for discussion, where everyone has the right to speak. The teacher also begins to speak by raising a finger and the general evaluation of the week is made. Questions, problems, solutions are discussed and common solutions are found.

In order to make students gain the awareness of democracy in the lessons activities are done. For example, a presentation is made to the whole class outside of the program, the students and the classroom teacher ask questions, compare them with their own languages and religions. It is emphasized that all languages and religions are important, they deserve respect, and one cannot say that only his language and religion are important. The aim is to raise awareness.

The project carried out in Lausanne can be shown as an example of the importance given to democracy education starting from pre-school education. Within the scope of the project initiated in cooperation with 3 private kindergartens in Lausanne, approximately 30-35 pre-school children are determined by lot every week. The children are taken to the centers where ballot boxes are set up, where the children vote. Children are aimed to learn about democracy. In this country famous for its referendum and initiative tradition, children are encouraged to participate in democracy at an early age. In the project, which emphasizes the importance of the development of reflexes against democracy at an early age, it is stated that children fulfill their roles seriously (EuroNews, 2021).

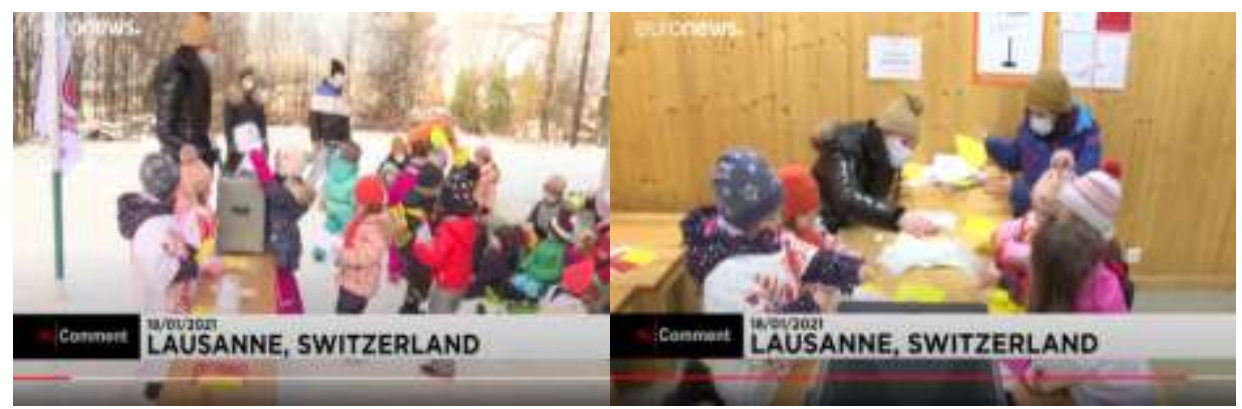

Figure 1

Preschool children are enabled to internalize democracy (EuroNews, 2021)

There are periodic project days / weeks in which many schools can be a part of this topic as extracurricular activities to raise awareness of democracy. Teachers can organize the projects together with community actors, or they can organize workshops by government or private institutions on any topic. Efforts to create a basis for cleaning habits or meeting with the society (elderly, refugees, religious communities, homeless...), youth parliament in the society, art projects, visits to mosques, churches, 
synagogues, festivals in schools can be cited as examples of this situation. Families also contribute to the aforementioned activities with food, etc.

In order to include family contribution in education for democracy, it is recommended that each member of the family respect the personality and integrity of each member, listen to the children and what they say, read newspapers and watch news on television and, most importantly, talk about these topics. It is emphasized that democracy is not only a right but also a duty and that democracy can be learned in the family in very early ages.

Regarding democracy education at the university, there are 2 lectures per week (Staatskunde), specific tutorials and seminars for 2 semesters (students choose workshops or seminars or determine a topic to study on). Besides, bottom-up "democratic process" is a part of the system in universities. You can see the best example of this very clearly at the University of Fribourg and the Federalism Institute. The democratic process has become a part of life.

Sincerely,

Prof. Asim Ari

Editor in Chief

Visiting Researcher/Lecturer at the Institute of Institute of Federalism

Federalism, University of Fribourg, Switzerland University of Fribourg, Switzerland

Email: asim.ari@unifr.ch

Website: http://www.federalism.ch
Dr. Nicolas Schmitt

\section{Guest Editor}

E-Mail: nicolas.schmitt@unifr.ch

Website: http://www.federalism.ch

\section{REFERENCES}

Ari, A. \& Stöckli, A. (2021). Switzerland Case as an Example of Success in Multicultural Education: From the Editor. International Journal of Instruction, 14(2), iiii. https://doi.org/10.29333/iji.2021.1420a.

EuroNews (2021). Preschool children are enabled to internalize democracy. https://www.euronews.com/2021/01/21/d-is-for-democracy-swiss-preschoolers-learn-tobe-good-citizens (Retrieved February 28, 2021)

Guest Researchers at the Institute of Federalism (2021). Retrieved from: https://www3.unifr.ch/federalism/en/research/guestresearcher.html (Retrieved January 17, 2021).

Lehrplan21 (2021). https://www.lehrplan21.ch (Retrieved April 03, 2021)

Politische Bildung (2021). http://politischebildung.ch (Retrieved April 03, 2021) 
Swissinfo (2021). Teaching students how to live democratically https://www.swissinfo.ch/eng/directdemocracy/political-education_teaching-studentshow-to-live-democratically/44859236 (Retrieved April 05, 2021)

Swiss Education System (2021). Retrieved from: https://www.sbfi.admin.ch/sbfi/en/home/education/swiss-education-area/swisseducation-system.html (Retrieved January 17, 2021). 